\title{
ПЕДАГОГИЧЕСКИЕ ИССАЕДОВАНИЯ
}

\section{EDUCATIONAL AND PEDAGOGICAL STUDIES}

DOI: 10.12731/2218-7405-2018-11-6-14

UDC 378

\section{PROBLEMS OF TEACHING ACADEMIC DISCIPLINES TO FOREIGN STUDENTS AT THE NORTHERN STATE MEDICAL UNIVERSITY}

\section{Khokhlova L.A., Dynkov S.M., Kiseleva L.G., Tikhonova E.V., Trokhova M.V., Kolodkina O.F.}

One of the success criteria of the university is the presence offoreign students. Their number in Russian higher educational establishments is increasing constantly. What often attracts foreign students is a possibility of getting education in English that is offered by some Russian universities. It greatly facilitates the learning process for foreigners and at the same time causes lots of problems for the faculty members teaching their disciplines in English. The manuscript objective is to generalize the experience of teaching clinical and theoretical disciplines to foreign students at the Northern State Medical University (NSMU).

Results. Some basic problems the faculty members face in the learning process have been revealed and analyzed.

Practical implications. Characteristic features of foreign students and problems occurring in the process of their education should be considered in the organization of academic activity and recommendations development for optimization of the adaptation process in the conditions of educational environment.

Keywords: foreign students; teaching problems; university; medicine. 


\title{
ПРОБЛЕМЫ ПРЕПОДАВАНИЯ УЧЕБНЫХ ДИСЦИПЛИН ИНОСТРАННЫМ СТУДЕНТАМ В СЕВЕРНОМ ГОСУДАРСТВЕННОМ МЕДИЦИНСКОМ УНИВЕРСИТЕТЕ
}

\author{
Хохлова Л.А., Дыньков С.М., Киселева Л.Г., \\ Тихонова Е.В., Трохова М.В., Колодкина О.Ф.
}

Одним из показателей успешности вуза является количество иностранных студентов, число которых в российских выстих учебных заведениях постоянно растет. Возможность получения образования на английском языке, которое предлагают некоторые российские вузы, - это то, что привлекает иностранцев. Преподавание на английском языке значительно облегчает прочесс обучения и в тоже время создает большое количество проблем для профессорско-преподавательского состава. Целью данной статьи является обобщение опыта преподавания клинических и теоретических дисииплин иностранным студентам в Северном государственном медииинском университете.

Результаты. Выявлены и проанализированы основные проблемы, с которыми сталкиваются преподаватели в ходе учебного процесса.

Область применения. Особенности иностранных студентов и проблемы, возникающие в прочессе их обучения, следует учитывать при организации учебного прочесса и разработке рекомендаций по оптимизации прочесса адаптации в условиях образовательной среды.

Ключевые слова: иностранные студенты; проблемы преподавания; университет; медицина.

One of the up-to-date criteria of the university effectiveness is the number of foreign students enrolled in academic programs of higher education. It reflects competitive ability and international recognition of the university $[1,2,3,5]$.

There are a lot of foreign students at the Northern State Medical University (Arkhangelsk) and their number is increasing constantly. Academ- 
ic disciplines both theoretical and clinical ones are taught in English as an international language of communication. Such a system of teaching poses a number of organizational, methodical, pedagogical and linguistic problems for the university and for each teacher in particular.

Among students studying in English at the NSMU, the Indians compose the main learning community. English is not a native language for both Indian students and the faculty members of the university. Teachers, while being accustomed to "classical" English taught in Russian schools, often have difficulty in communicating with foreign students. Peculiarities of Indian English often make it difficult for the teachers to understand words pronunciation and their meaning. Language barrier as well as the insufficient number of teachers who are capable of delivering lectures in English are therefore the main problems of teaching foreign students.

In some cases, educational background of foreign students is behind that of the Russian ones and their learning motivation is often considerably lower. From the viewpoint of organizational issues, it should be noted that foreign students are often late for their practical classes and lectures and many absences are without valid excuse. Sometimes they consider it unnecessary to do their home assignment or take study materials from the library. Their behavior can be bad and they can prevent the teacher from conducting the class. It takes a long time for foreigners to start understanding the dos and don'ts of polite manners and traditions of Russian education. This all makes the educational process more complicated.

There are also objective learning difficulties associated with living in a foreign country. Indian students are more likely than the Russian ones to suffer from respiratory diseases. It is partly due to specific climatic and geographical reasons. Arriving in September for the training in Arkhangelsk, they find themselves at the beginning of the cold season and do not always have time to physiologically acclimatize.

Therefore, training and coordinating groups of foreign students coming from a different cultural and linguistic environment is not an easy task [4]. The teacher requires certain severity to organize the learning process, to control class and late attendances. Working with foreign students the teacher has to consider ethnic peculiarities, students' mother 
tongue, the level of their educational background, career choice motivation and their efforts to master competences necessary for a medical specialty. Indian students are distinguished by their vivid emotionality, the necessity of a rapid activity change often interpreted as a lack of patience. A variety of attention-getting methods is a kind of problem solution in this case. Case studies, information technologies in the form of presentations and online searching, skill training on phantoms and group work can be used in teaching foreign students [6]. Indian students like specific tasks when they can see and try some devices (inhalers, nebulizers, pulse oximeters). To maintain students' attention during practical classes and lectures, it is effective to use question-answer methods and to give hands-on examples that are always of particular interest to students.

A significant aspect of teaching foreign students is their practical training taking place in different departments of Arkhangelsk clinical hospitals. During the practical training, they do the work of assistant doctors. They participate in daily rounds, diagnostic procedures (endoscopy, ultrasound examination, CT, X-ray examination), operations and dressings. To follow such a course of teaching foreign students, certain level of knowledge of the Russian language is thought to be absolutely necessary. Foreign students with a poor knowledge of Russian cannot communicate with patients and are not able to get necessary information during patient's examination. There is certain logic: the better the student speaks Russian, the better achievements he/she has in clinical disciplines. It is likely to be due to initially better abilities and efforts.

In the opinion of clinical department teachers, the two-step training is a more rational approach in the organization of the learning process. In the first and third years, it is acceptable to deliver lectures in English, but in the fourth and sixth years, it seems more reasonable to conduct classes in Russian. It might increase students' motivation to learn Russian and improve their skill and knowledge they can gain in clinical departments.

Groups of 8-9 students are ideal for the work in clinical departments. In this case, students can practice their skills in patient's examination and disease diagnostics more effectively. Large academic groups fail to ensure such possibilities and are an additional stressing for the teach- 
er during practical classes as well as for the department where students have their practical training.

Speaking about the problems of teaching foreign students one cannot but mention the methodological component of the educational process. An important aspect is the availability of study materials. In comparison with foreign universities, there is a certain discrepancy of our subjects. We lack special educational literature in English, which would be adapted to our curricula. For example, General Surgery is not taught in foreign universities and there are no English textbooks that can be used in the course of lectures and classes in the given discipline. The subject of pathology is studied in many European countries and in India. In Russia, medical students study pathologic physiology and pathologic anatomy. As a result, it is the information on pathologic anatomy that is mostly presented in textbooks. Pathophysiology issues are paid little attention to and are practically not considered. One has to synthesize and think something up to give students an idea of the studied material. The most complicated questions are to be explained twice and even three times. Problems with understanding weaken the students' learning interest and their motivation to gain knowledge.

The other side of the question is the preparation of own study materials, textbooks and workbooks in English. Unfortunately, it often becomes a problem of teachers and their departments but not of the university.

\section{Conclusions}

Teaching foreign students in English is a necessary component of the image of the medical university. It allows viewing the university as an internationally recognized educational establishment. Quality training of foreign students requires language proficiency of the faculty members, their regular skill improvement in this field, modern material and technological facilities, information and library resources as well as students' adaptation system.

\section{References}

1. Arkhipov A.Yu., Rogova T.M., Savchenkova I.N. Vysshie uchebnye zavedeniya $\mathrm{v}$ privlechenii, obuchenii i adaptatsii inostrannykh studentov 
[Higher Educational Establishments in Recruiting, Education and Adaptation of Foreign Students]. Terra Economicus, 2013, pp. 32-37.

2. Filimonova N.Yu., Godenko A.E. Eksport obrazovatel'nykh uslug kak sostavlyayushchaya mezhdunarodnoy deyatel'nosti vuzov [Export of Educational Services as a Component of the International Activities of Universities]. Privolzhskiy nauchnyy vestnik, 2014, pp. 15-18.

3. Galyamova E.F., Kudimana G.O. Privlekatel'nost' rossiyskikh vuzov na mezhdunarodnom rynke obrazovatel'nykh uslug [The Attractiveness of Russian Universities in the International Market of Educational Services]. Vestnik Udmurtskogo universiteta. Seriya «Ekonomika i pravo», 2017, pp. 5-9.

4. Kapezina T.T. Problemy obucheniya inostrannykh studentov v rossiyskom vuze [Problems of Teaching Foreign Students in Russian Universities]. Nauka. Obshchestvo. Gosudarstvo, 2014. C. 13-17.

5. Korobkova S.A., Smykovskaya T.K. Spetsifika obucheniya inostrannykh studentov fizike i matematike v vuzakh Rossii [The specifics of teaching foreign students physics and mathematics in Russian universities]. Izvestiya Volgogradskogo gosudarstvennogo pedagogicheskogo universiteta. 2017. № 7 (120), pp. 63-68.

6. Solov'eva N.A., Polyakova N.S. Interaktivnye metody obucheniya inostrannykh slushateley podgotovitel'nogo otdeleniya [Interactive methods of teaching foreign students of the preparatory department]. Sovremennye problemy nauki i obrazovaniya. 2016. № 2. http://www.science-education.ru/ru/article/view?id=24339

\section{Список литературы}

1. Архипов А.Ю., Рогова Т.М., Савченкова И.Н. Высшие учебные заведения в привлечении, обучении и адаптации иностранных студентов // Terra Economicus, 2013. C. 32-37.

2. Филимонова Н.Ю., Годенко А.Е. Экспорт образовательных услуг как составляющая международной деятельности вузов // Приволжский научный вестник, 2014. С. 15-18.

3. Галямова Э.Ф., Кудимана Г.О. Привлекательность российских вузов на международном рынке образовательных услуг // Вестник Удмуртского университета. Серия «Экономика и право», 2017. С. 5-9. 
4. Капезина Т.Т. Проблемы обучения иностранных студентов в российском вузе // Наука. Общество. Государство, 2014. С. 13-17.

5. Коробкова С.А., Смыковская Т.К. Специфика обучения иностранных студентов физике и математике в вузах России // Известия Волгоградского государственного педагогического университета. 2017. № 7 (120). С. 63-68.

6. Соловьёва Н.А., Полякова Н.С. Интерактивные методы обучения иностранных слушателей подготовительного отделения // Современные проблемы науки и образования. 2016. № 2. http://www.scienceeducation.ru/ru/article/view?id=24339

\section{DATA ABOUT THE AUTHORS}

Khokhlova Larissa Aleksandrovna, Associate Professor, Foreign Language Department, PhD in Psychophysiology

Northern State Medical University

51, Troitskiy Ave., Arkhangelsk, 163000, Russian Federation lkhokhlova@rambler.ru

SPIN-code: 8698-0280

Dynkov Sergey Mikhaylovich, Professor, Surgery Department, MD Northern State Medical University 51, Troitskiy Ave., Arkhangelsk, 163000, Russian Federation dincov08@rambler.ru

Kiseleva Larissa Grigorevna, Associate Professor, Neonatology and Perinatology Department, $\mathrm{PhD}$ in Medicine Northern State Medical University 51, Troitskiy Ave., Arkhangelsk, 163000, Russian Federation kis272@yandex.ru SPIN-code: 9774-3360

Tikhonova Elena Vasilevna, Associate Professor, Pathologic Physiology Department, PhD in Medicine Northern State Medical University 
51, Troitskiy Ave., Arkhangelsk, 163000, Russian Federation tiholog@mail.ru

SPIN-code: $7400-0146$

ORCID: 0000-0001-8792-5847

Trokhova Mariya Vasilevna, Associate Professor, Department of Family Medicine and Internal Diseases, $\mathrm{PhD}$ in Medicine Northern State Medical University 51, Troitskiy Ave., Arkhangelsk, 163000, Russian Federation mtrokhova@mail.ru SPIN-code: 7534-3479

Kolodkina Olga Feliksovna, Professor, Department of Hospital Therapy and Endocrinology, $\mathrm{PhD}$ in Medicine Northern State Medical University 51, Troitskiy Ave., Arkhangelsk, 163000, Russian Federation olgafk@yandex.ru

\section{ДАННЫЕ ОБ АВТОРАХ}

Хохлова Лариса Александровна, доцент кафедры иностранных языков, кандидат биологических наук Северный государственный медицинский университет пр. Троицкий, 51, г. Архангельск, 163000, Российская Федерация lkhokhlova@rambler.ru

Дыньков Сергей Михайлович, профессор кафедры хирургии, доктор медицинских наук Северный государственный медицинский университет пр. Троиџкий, 51, г. Архангельск, 163000, Российская Федераџия dincov08@rambler.ru

Киселева Лариса Григорьевна, доцент кафедры неонатологии и перинатологии, кандидат медицинских наук Северный государственный медищинский университет 
пр. Трочичкий, 51, г. Архангельск, 163000, Российская Федераџия kis272@yandex.ru

Тихонова Елена Васильевна, доцент кафедры патологической физиологии, кандидат медицинских наук

Северный государственный медицинский университет пр. Трочикий, 51, г. Архангельск, 163000, Российская Федерация tiholog@mail.ru

Трохова Мария Васильевна, доцент кафедры семейной медицины и внутренних болезней, кандидат медицинских наук Северный государственный медищинский университет пр. Троищкий, 51, г. Архангельск, 163000, Российская Федераичи mtrokhova@mail.ru

Колодкина Ольга Феликсовна, доцент кафедры госпитальной терапии и эндокринологии, кандидат медицинских наук Северный государственный медицинский университет пр. Трочикий, 51, г. Архангельск, 163000, Российская Федераџия olgafk@yandex.ru 